\title{
Geographic variation of Moenkhausia bonita (Characiformes: Characidae) in the rio de la Plata basin, with distributional comments
}

\author{
on M. intermedia
}

\author{
James Anyelo Vanegas-Ríos ${ }^{1}$, Ricardo Britzke ${ }^{2,3}$ and Juan Marcos Mirande ${ }^{4}$
}

\begin{abstract}
Moenkhausia bonita occurs in numerous additional localities from the Bermejo, Paraná, Paraguay, and Uruguay river basins. Given that this finding greatly expands the distributional range of $M$. bonita, we carried out an intraspecific comparison, using multivariate methods for 18 morphometric and eight meristic characters taken from a comprehensive sample of 536 specimens. All localities were distributed in four major geographic groups as follows: Bermejo, Paraná, Paraguay, and Uruguay. Results of the morphometric comparisons showed significant differences among the studied groups except between the Paraguay and Uruguay groups. Statistical differences in meristic values were found for most between-group comparisons, especially in those resulting from discriminant canonical analyses (DCA). Specimens from the Bermejo basin were the most distinct group in most morphological comparisons. However, the overall subtle differences found in body morphology likely reflect intraspecific variation within $M$. bonita and seem to be mainly influenced by spatial and environmental features of drainages. As $M$. bonita was previously identified as M. intermedia in the río de La Plata basin, distributional comments on the latter species in that basin are provided.
\end{abstract}

Keywords: Allometry, Argentina, Moenkhausia, Morphological variation, Widespread species.

Moenkhausia bonita es registrada en numerosas localidades adicionales de las cuencas de los ríos Bermejo, Paraná, Paraguay, y Uruguay. Dado que estos hallazgos expanden ampliamente el rango distribucional de $M$. bonita, nosotros llevamos a cabo una comparación intraespecífica, usando métodos multivariados para 18 características morfométricas y 8 merísticas que fueron tomados en una muestra exhaustiva de 536 especímenes. Todas las localidades fueron repartidas en cuatro grupos principales como sigue: Bermejo, Paraná, Paraguay y Uruguay. Los resultados de las comparaciones morfométricas mostraron diferencias significativas a través de los grupos bajo estudio, excepto entre los grupos Paraguay y Uruguay. Diferencias estadísticas fueron encontrados en la mayoría de las comparaciones entre los grupos, especialmente en aquellas obtenidas de los análisis discriminantes canónicos (ADC). Los especímenes de la cuenca del Bermejo fueron encontrados como el grupo más divergente en la mayoría de las comparaciones morfológicas. No obstante, estas leves diferencias encontradas en la morfología del cuerpo son consideradas dentro de la variación intraespecífica de $M$. bonita y parecen estar influidas por características ambientales y espaciales de los drenajes. Dado que M. bonita fue previamente identificada como M. intermedia en la cuenca del río de La Plata, comentarios distribucionales sobre esta última especie en esta cuenca son presentados.

Palabras clave: Alometría, Argentina, Moenkhausia, Variación morfológica, Especie ampliamente distribuida.

\section{Introduction}

With 5,160 valid species, Neotropical freshwater fishes represent approximately one-third of global freshwater fish diversity (Reis et al., 2016). In general, the distribution of continental fish species at regional scales can be separated into two broad patterns: 1) the majority of species have confined distributions circumscribed by regional or geographic boundaries with sporadic occurrences beyond; and 2) a few species have large spatial distributions, extending to multiple basins, even across different biogeographic regions (Albert et al., 2011). Numerous factors, in isolation or in combination, have been put forward to potentially explain how species managed to reach

\footnotetext{
${ }^{1}$ División Zoología de Vertebrados, Facultad de Ciencias Naturales y Museo, CONICET, UNLP, Paseo del Bosque S/N B1900FWA, La Plata, Buenos Aires, Argentina. anyelovr@fcnym.unlp.edu.ar, Ohttps://orcid.org/0000-0001-9356-7687 (corresponding author).

${ }^{2}$ Departamento de Morfologia, Instituto de Biociências Universidade Estadual Paulista, 18618-970 Botucatu, São Paulo, Brazil. britzker@gmail.com, Dhttps://orcid.org/0000-0002-1042-2544

${ }^{3}$ Universidad Técnica de Machala, Av. Panamericana km 51/2, Via Pasaje, Machala, El Oro, Ecuador.

${ }^{4}$ Fundación Miguel Lillo, UEL-CONICET, San Miguel de Tucumán, Argentina. mcmirande@gmail.com, Dhttps://orcid.org/0000-0003-4370-3526
} 
such geographic ranges (reviewed in Gaston, 2003). These factors include changes in niche breadth, demographic dynamics, body size, environmental variability, colonization and extinction dynamics, and dispersal ability, among others (Gaston, 2003; Lomolino et al., 2010; Albert, Reis, 2011; García-Vázquez, Ribera, 2016). In many cases, widespread species require comprehensive taxonomic analyses in order to understand their distributional patterns (Albert et al., 2011; Reis et al., 2016).

The genus Moenkhausia Eigenmann is composed of 90 valid species that are widely distributed in most important cis-Andean river basins in South America (e.g. Amazon, Orinoco, La Plata, and San Francisco). This genus reaches its greatest diversity in the rio Amazon basin ( 73 species), followed by the coastal basins of Guyana, Suriname, and French Guiana ( 14) (Lima et al., 2003; Britzke et al., 2018; Fricke et al., 2019). The morphological definition of Moenkhausia is based on a combination of non-exclusive characteristics (e.g. presence of five teeth in the inner tooth row of the premaxilla, presence of small scales covering the bases of the anal and caudal fins, and a complete lateral line, see Eigenmann, 1917 for further details) that are highly homoplastic and shared in part with other characid genera such as Astyanax Baird \& Girard or Hemigrammus Gill. Additionally, the genus has been recognized as non-monophyletic by morphological and molecular analyses (Mirande, 2010; Mariguela et al., 2013).

Examples of broadly distributed members of Moenkhausia include $M$. dichroura (Kner), $M$. intermedia Eigenmann, M. lepidura (Kner), M. megalops (Eigenmann), and M. oligolepis (Günther) (Benine et al., 2009; Britzke, 2011; Marinho, Langeani, 2016; Soares et al., 2017). In the rio de la Plata basin, seven species of Moenkhausia have been recorded: $M$. australe Eigenmann; M. bonita Benine, Castro \& Sabino; M. dichroura; M. forestii Benine, Mariguela \& Oliveira; M. intermedia; M. lopesi Britski \& de Silimon; and M. sanctaefilomenae (Steindachner) (Britski, Silimon, 2001; Benine et al., 2004; Benine et al., 2009; Fricke et al., 2019).

Moenkhausia bonita is a relatively small-sized species (up to $44 \mathrm{~mm}$ of SL) that, although described as endemic to its type locality (the rio Baía Bonita, a tributary of the rio Miranda), has been subsequently recorded in other localities from the Paraguay and Amazon river basins (Benine et al., 2004; Teresa, Romero, 2010; Teresa et al., 2010; Teresa et al., 2011; Castro, Vizzotto, 2013; Lima et al., 2013; Queiroz et al., 2013; Cordeiro et al., 2014). Recently, M. bonita has been phylogenetically placed into the "Moenkhausia clade" as defined by Mirande (2018), which also includes the type species of the genus.

Preliminary results obtained by examination of a large sample of specimens, previously identified as Moenkhausia intermedia or $M$. cf. intermedia, from the Bermejo, Paraná, and Uruguay basins allowed us to conclude that all these specimens correspond to $M$. bonita, based on the number of gill rakers (6-8 + 11-15 in M. bonita vs. 9-12+18-22 M. intermedia) (see Benine et al., 2004; Britzke, 2011). This finding greatly expands the occurrence range of $M$. bonita to a great portion of the rio de la Plata basin. In order to explore the possible existence of cryptic species within this widespread range (especially the Bermejo specimens that are most distantly located) and to examine the morphological heterogeneity of spatially distinct populations, we conducted a geographic and population comparison of $M$. bonita in the río de La Plata basin, based on a comprehensive morphological dataset. Additionally, we provide distributional comments on $M$. intermedia in that basin.

\section{Material and Methods}

Data collection. Five hundred and thirty-six specimens of $M$. bonita were examined in order to include a representative sampling of its distributional range in the rio de la Plata basin. From the total number of examined specimens, 220 were fully measured and 317 were only partly measured (because they were available only temporarily). Although those specimens with partial data were not included in the statistical comparisons and reporting tables, they were unequivocally identified as $M$. bonita to more completely examine the morphology of this species across its geographic range. Data for the holotype follows Benine et al. (2004). Additionally, specimens of $M$. dichroura (177), $M$. intermedia (29), and M. sanctaefilomenae (6) were examined for comparative purposes. Institutional abbreviations used in the text follow Sabaj (2016).

Morphological data. Meristic and morphometric characteristics were used to analyze the intraspecific variation of $M$. bonita and to corroborate the identification of all examined specimens. All measurements and counts were taken according to Fink, Weitzman (1974). The following 18 morphometric variables were taken: standard length (SL), depth at dorsal-fin origin, snout to dorsal-fin origin, snout to pectoral-fin origin, snout to pelvic-fin origin, snout to anal-fin origin, dorsal-fin origin to caudal-fin base, dorsal-fin length, pectoral-fin length, pelvic-fin length, anal-fin lobe length, caudal peduncle depth, caudal peduncle length, head length (HL), snout length, horizontal eye length, least interorbital width, and upper jaw length. Measurements were taken point to point with digital calipers under a stereomicroscope and are expressed as percentages of SL or HL for units of the head. Those meristic variables that varied most intraspecifically, were analyzed statistically: lateral line scales, scales below the lateral line, circumpeduncular scales, branched anal-fin rays, maxillary teeth, teeth in the outer premaxillary row, and gill rakers of the first gill arch (separate counts for the lower and upper limbs). Other counts such as the scales above the lateral line, predorsal scales, dorsal-fin rays, pectoral-fin rays, pelvic-fin rays, and teeth in the inner premaxillary row, which were not statistically analyzed due to their almost uniform distribution across the groups or non-significant sample size (only for vertebral counts), are provided to characterize the species for identification purposes. 
Total number of vertebrae were counted in cleared and counterstained (c\&s) specimens, which were prepared following Taylor, Dyke (1985). Those counts include the first preural centrum plus first ural centrum (PU1+U1) counted as one element and all four vertebrae of the Weberian apparatus. Other osteological characteristics were compared but only substantial differences are reported if observed.

Sex identification was based on gonadal examination and/or the presence of secondary sexual characteristics if present. Not all samples were collected in the same seasons, and those specimens collected outside the breeding season lacked secondary sexual characteristics and were not assignable to one sex or the other. Sexually dimorphic characteristics found are reported. Sexual variation could not be statistically analyzed in detail, because significant samples of mature male specimens were not available for all groups.

Statistical analysis. All localities of occurrence of $M$. bonita were divided into four major geographic areas (named as groups: Bermejo, Paraguay, Paraná, and Uruguay), which represents the most important sub-basins of the rio de la Plata basin in which this species occurs. The selection of these groups was based on hydrogeographic and ichthyofaunistic differences that characterize each basin (Quirós et al. 2007; Albert, Reis, 2011). The geographic distribution of the analyzed samples within the rio de la Plata basin is plotted in Fig. 1. These localities ranges from 55 to $492 \mathrm{~m}$ above sea level.

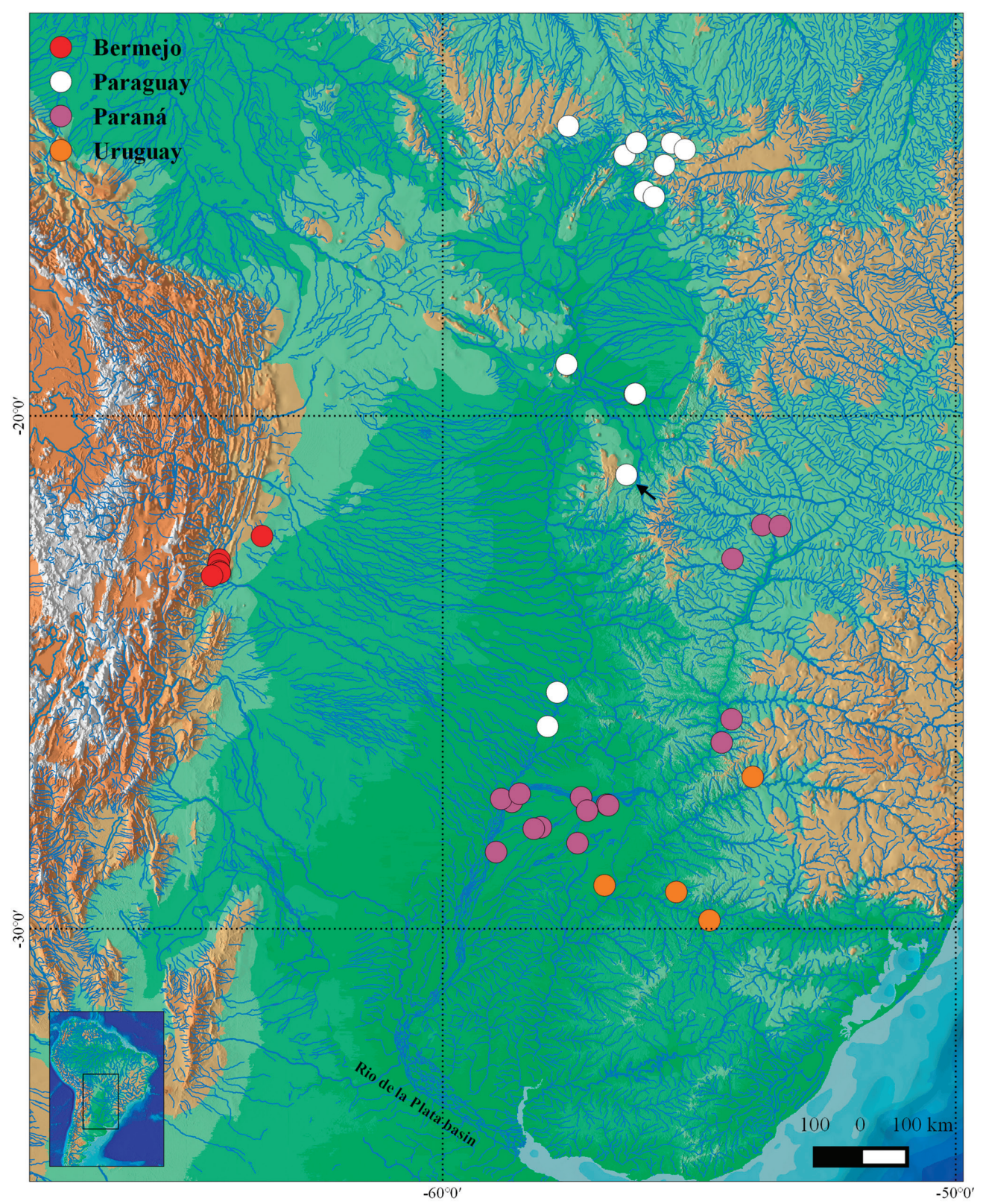

Fig. 1. Map showing the distributional range of Moenkhausia bonita across the rio de la Plata basin (based on the examined specimens). Black arrow indicates type locality. 
Morphometric and meristic data were analyzed separately, because these type of variables differ statistically and biologically and because they may respond differently to environmental and genetic conditions (Lawing et al., 2008; Hair et al., 2010). The allometric coefficient or $k$ (Huxley, 1932; Klingenberg, 1996) of all measurements was obtained for each analyzed group (reference size used: SL) using a least-square based regression line of base-10 log-transformed data (see Kilmer, Rodríguez, 2017 for details on the preferable use of the ordinary least square algorithm in comparison with other methods). The regression plots were used to evaluate whether allometries differed among groups, but only those plots showing pertinent differences are reported. In order to study the size-free shape differences among groups, the morphometric data were treated with Burnaby's allometric correction (Burnaby, 1966; Humphries et al., 1981; Rohlf, Bookstein, 1987). In that method, the morphometric variables are log-transformed and then are projected onto a space orthogonal to the first principal component, which typically removes size-dependent shape variation from the dataset. The size-corrected morphometric data for each studied group were analyzed by means of a principal component analysis (PCA) and a discriminant canonical analysis (DCA), using the covariance matrix in both cases. For the PCA analyses, the number of significant components was determined using the broken-stick model (Frontier, 1976) and the scree plot method (Cattel, 1966), including the larger number of biologically meaningful axes if they disagreed. In the DCA analysis, the Mahalanobis distances were calculated from the pooled within-group covariance matrix to obtain a linear discriminant classifier. The confusion matrix obtained from these calculations indicates the number of specimens in each group that were assigned to the different groups by the classifier. The group assignment was cross-validated by a leave-one-out cross-validation procedure using jackknifing.

Meristic data were square-root transformed (Quinn, Keough, 2002) and then analyzed with PCA (using the correlation matrix) and DCA. Resultant axes of all the multivariate analyses that showed a great overlap among individuals are not depicted here. Additionally, Tukey box plots were used to graphically represent those counts showing major differences among the studied groups. To test the significance of the resulting shape and meristic scores of the most discriminative axes found in PCA and DCA, a Kruskal-Wallis test plus Mann-Whitney pairwise comparisons were performed. All such analyses used the Bonferroni-corrected $p$ values. Finally, a Mantel test was used to assess possible correlation between the morphometric and meristic matrices using Mahalanobis distances.

For statistics methods used here see Marcus (1990), Reyment (1990), Quinn, Keough (2002), and Hair et al. (2010). Prior to all statistical procedures performed, the data were examined for departures from statistical assumptions (normality and deviation from equality of variances), and were adjusted when necessary (logarithmic and root square transformations). Multivariate normality was assessed using the omnibus test of Doornik, Hansen (2008). Statistical significance was assessed at $p<0.05$. All statistical analyses were carried out in PAST 3.14 (Hammer et al., 2001) and, complementarily, Sigma Plot 12 (2011, Systat Software, Inc. Windows).

\section{Results}

Morphometric data. The measurements are summarized in Tab. 1. Comparing the allometric coefficients $(k)$, different combinations of negative and positive allometry, and isometry were found among the studied groups (Tab. 1). The depth at dorsal-fin origin (positive allometry: $k=1.1$ ), snout to pectoral-fin origin (negative allometry: $k$ ranging from 0.6 to 0.8 ), anal-fin lobe length (negative allometry: $k$ ranging from 0.4 to 0.8 ), and head length (negative allometry: $k$ ranging from 0.6 to 0.9 ) showed similar patterns of biometric growth relative to body size (SL) across the groups. The majority of the measurements expressed as percentages of standard length varied among the groups in their allometric coefficients, with the Bermejo and Uruguay groups often negatively allometric and the Paraguay group often positively allometric. In measurements expressed as percentages of head length, almost all the groups showed negative allometry, except the Paraguay group with isometry in the least interorbital width and positive allometry in the snout length. Regression plots for most measurements with differing allometric coefficients did not completely separate the groups. However, regressions of snout length, upper jaw length, and pelvic-fin length, differed slightly among the groups, thereby allowing the partial discrimination of many individuals of the Paraguay group (S1 Available only as online supplementary file accessed with the online version of the article at http://www.scielo.br/ni). These same variables were also informative in the multivariate comparisons (mentioned below).

According to the scree plot method, between four and six relevant components should be selected, because the curve flattens after the fourth component but still shows a break point between the fifth and sixth eigenvalues (Tab. 2). Conversely, the broken-stick model suggested using only the first component (see S2 - Available only as online supplementary file accessed with the online version of the article at http://www. scielo.br/ni). In order to ensure that did not discard biologically relevant data, we chose a consensus between the two methods and extracted four eigenvector elements (of PCs) that accounted for $74.4 \%$ of the total variance (Tab. 2). The plot of the first principal component (PC1) vs. the second principal component (PC2) (Fig. 2a, representing $59.3 \%$ of the total variance) suggests that the individuals of the Bermejo group mainly separated from the individuals of the Paraná group along PC2, but not from those of the remaining groups. PC1 was loaded most heavily by the following measurements: negatively by caudal peduncle length (-0.75) and upper jaw length $(-0.24)$; and positively by the dorsal-fin origin to caudal-fin base ( 0.23$)$, snout to anal-fin origin $(0.21)$, and snout to dorsal-fin origin $(0.21)$. The positive loadings that most influenced PC2 were the snout length (0.64) and upper jaw length (0.34), whereas the negative loadings that most affected that component were 


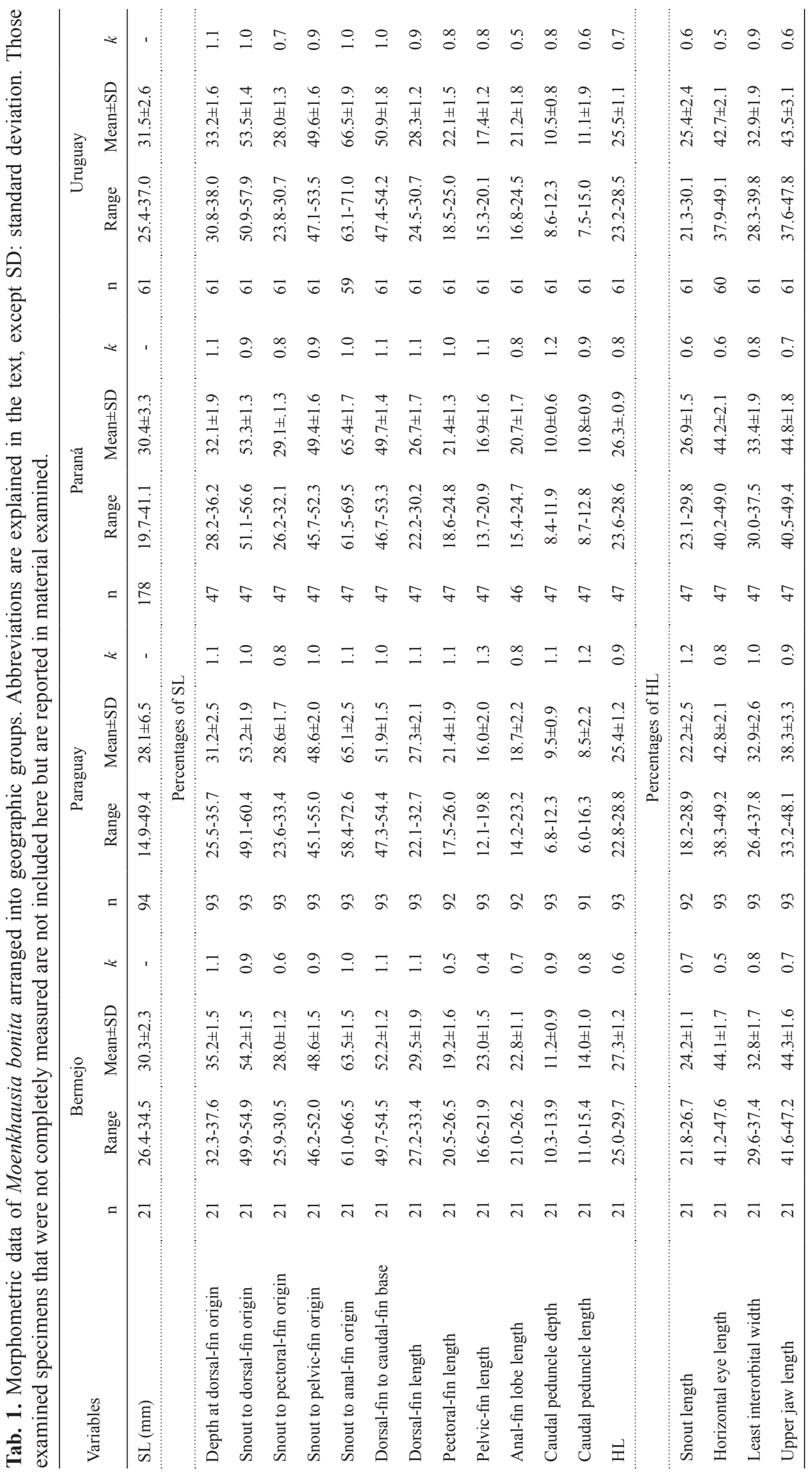


pelvic-fin length $(-0.37)$, caudal peduncle length $(-0.29)$, pectoral-fin length (-0.24), and dorsal-fin length (-0.23). A table of the morphometric loadings can be found in $\mathbf{S 3}$ - Available only as online supplementary file accessed with the online version of the article at http://www.scielo.br/ni. The plot of the PC3 vs. PC4 (representing a $15.2 \%$ of the total variance) does not separate the studied groups and for this reason, is not presented.

Size-free DCA accounted for $85.3 \%$ of the total variance in the first two canonical axes (CA) (Tab. 2). Along the plot of the first canonical axis (CA1) vs. the second canonical axis (CA2) (Fig. 2b), the individuals of the Bermejo group were well discriminated from the remaining individuals along CA1, while CA2 partly discriminated the individuals of the Paraná group. The most important loadings affecting CA1 was the caudal peduncle length $(-0.03)$, snout to anal-fin origin $(0.01)$, snout to dorsal-fin origin (0.01), and snout to pectoral-fin origin (0.01), while CA2 was most influenced by the snout length (0.02), upper jaw length (0.02), caudal peduncle length $(0.01)$, dorsal-fin length (0.01), and dorsal-fin origin to caudal-fin base (0.01). A list of the morphometric loadings can be found in S3 - Available only as online supplementary file accessed with the online version of the article at http://www. scielo.br/ni. In the confusion matrix, $70.0 \%$ of all the examined individuals were correctly classified to their given group ( $75.0 \%$ if the data were not jackknifed), with those individuals of the Bermejo and Paraná groups being most frequently classified correctly (100 and $87.2 \%$, respectively) (Tab. 3).

Tab. 2. Results of the principal components analyses (PCA) and discriminant canonical analyses (DCA) of the adjusted morphological data of Moenkhausia bonita.

\begin{tabular}{|c|c|c|c|c|}
\hline \multirow{2}{*}{ Axes } & \multicolumn{2}{|c|}{ Morphometric data } & \multicolumn{2}{|c|}{ Meristic data } \\
\hline & Eigenvalue & $\%$ Variance & Eigenvalue & $\%$ Variance \\
\hline \multicolumn{5}{|c|}{ (PCA) } \\
\hline 1 & 0.0093 & 46.3 & 2.3896 & 29.9 \\
\hline 2 & 0.0026 & 12.9 & 1.5275 & 19.1 \\
\hline 3 & 0.0018 & 8.8 & 1.2475 & 15.6 \\
\hline 4 & 0.0013 & 6.4 & 0.8448 & 10.6 \\
\hline 5 & 0.0011 & 5.6 & 0.6754 & 8.4 \\
\hline 6 & 0.0008 & 4.1 & 0.5496 & 6.9 \\
\hline 7 & 0.0007 & 3.3 & 0.4220 & 5.3 \\
\hline 8 & 0.0006 & 2.8 & 0.3437 & 4.3 \\
\hline 9 & 0.0005 & 2.4 & - & - \\
\hline 10 & 0.0004 & 1.9 & - & - \\
\hline 11 & 0.0004 & 1.7 & - & - \\
\hline 12 & 0.0002 & 1.2 & - & - \\
\hline 13 & 0.0002 & 0.8 & - & - \\
\hline 14 & 0.0001 & 0.6 & - & - \\
\hline 15 & 0.0001 & 0.5 & - & - \\
\hline 16 & 0.0001 & 0.3 & - & - \\
\hline 17 & 0.0000 & 0.2 & - & - \\
\hline 18 & 0.0000 & 0.0 & - & - \\
\hline \multicolumn{5}{|c|}{ (DCA) } \\
\hline 1 & 1.2100 & 44.3 & 6.4836 & 77.3 \\
\hline 2 & 1.1190 & 41.0 & 1.5130 & 18.0 \\
\hline 3 & 0.4027 & 14.7 & 0.3912 & 4.7 \\
\hline
\end{tabular}
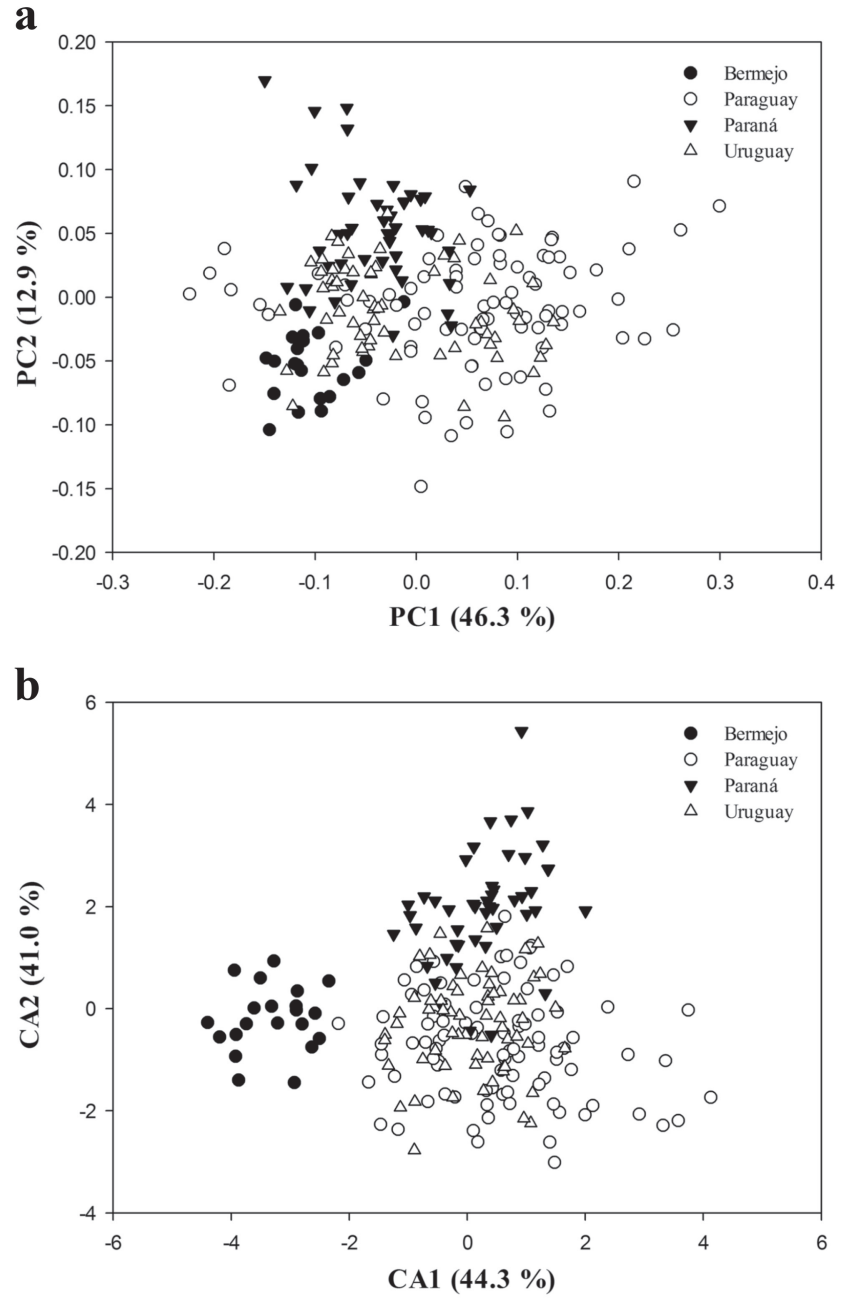

Fig. 2. Most discriminant axes obtained from the size-free multivariate analyses using the adjusted morphometric data of Moenkhausia bonita. a. principal component analysis; b. discriminant canonical analysis.

Tab. 3. Confusion matrix showing classification of Moenkhausia bonita to geographic group using the adjusted morphometric (A) and meristic (B) data (bold values indicate correct classifications). Column: predicted group, rows: given group.

\begin{tabular}{|c|c|c|c|c|c|c|}
\hline Groups & Bermejo & Paraguay & Paraná & Uruguay & Total & $\%$ Correct \\
\hline \multicolumn{7}{|c|}{ (A) } \\
\hline Bermejo & 21 & 0 & 0 & 0 & 21 & 100.0 \\
\hline Paraguay & 5 & 48 & 10 & 26 & 89 & 53.9 \\
\hline Paraná & 0 & 2 & 41 & 4 & 47 & 87.2 \\
\hline Uruguay & 0 & 14 & 5 & 44 & 63 & 69.8 \\
\hline Total & 26 & 64 & 56 & 74 & 220 & \\
\hline \multicolumn{7}{|c|}{ (B) } \\
\hline Bermejo & 21 & 0 & 0 & 0 & 21 & 100.0 \\
\hline Paraguay & 0 & 74 & 0 & 16 & 90 & 82.2 \\
\hline Paraná & 3 & 0 & 27 & 9 & 39 & 69.2 \\
\hline Uruguay & 0 & 17 & 10 & 39 & 66 & 59.1 \\
\hline Total & 24 & 91 & 37 & 64 & 216 & \\
\hline
\end{tabular}


The results of the Kruskal-Wallis tests, comparing the shape scores along the most discriminative PCA axes, were statistically significant for PC1 and PC2 (Tab. 4). Based on the post hoc pairwise comparisons, significant differences were detected across all the groups in PC1 and PC2 except between the Paraná and Uruguay groups, and between the Paraguay and Uruguay groups, respectively (Tab. 4). The results of the Kruskal-Wallis tests, using the resultant meristic scores, were found to be statistically significant; the post hoc pairwise tests detected significant differences for most group comparisons except between the Paraguay and Uruguay groups in CA1 and CA2, and between the Bermejo and Paraná groups in CA2 (Tab. 4).

Meristic data. All the meristic variables are presented in Tab. 5. The scree plot and broken-stick methods indicated a similar number of significant components ranging between three and five (but both with more than one possible break point). The first four components were cho- sen based on the same criteria used for the morphometric data. PC1 produced by the square-root transformed data accounted for $29.9 \%$ of the total variance, PC2 accounted for $19.1 \%$, while PC3 and PC4 accounted for 15.6 and $10.6 \%$, respectively (Tab. 2). The plot of the PC1 vs. PC2 (Fig. 3a) shows that the individuals of the Bermejo group were separated from most individuals of the other groups except those of the Paraná group, especially along PC2, while the individuals of the Paraná, Paraguay, and Uruguay groups overlapped partially along both axes. PC1 was loaded most heavily by the number of lateral line scales $(0.51)$, circumpeduncular scales $(-0.50)$, teeth in the outer premaxillary row $(0.44)$, and maxillary teeth $(-0.40)$. The loadings that most influenced PC2 were all positive, and include: number of scales below the lateral line (0.58), gill rakers on the upper limb (0.54), branched anal-fin rays (0.37), and gill rakers on the upper limp (0.31). PC3 and PC4 do not separate any groups and thus those plots and results are not shown.

Tab. 4. Results of Kruskall-Wallis (KW) tests and Mann-whitney $(U)$ pairwise comparisons (based on the Bonferronicorrected $p$ values) of the resultant shape and meristic scores of principal component analysis (PCA) and discriminant canonical analysis (DCA). $U$ values: below diagonal; multivariate normality: MN; $p$ values are expressed as $<0.05$ or $>0.05$ (significant results in bold).

\begin{tabular}{|c|c|c|c|c|c|c|c|c|c|}
\hline & & \multicolumn{4}{|c|}{ Morphometric scores } & \multicolumn{4}{|c|}{ Meristic scores } \\
\hline & & Bermejo & Paraguay & Paraná & Uruguay & Bermejo & Paraguay & Paraná & Uruguay \\
\hline \multicolumn{10}{|c|}{ (PCA) } \\
\hline \multirow{6}{*}{ PC1 } & Bermejo & - & $<0.05$ & $<0.05$ & $<0.05$ & - & $<0.05$ & $>0.05$ & $>0.05$ \\
\hline & Paraguay & 169 & - & $<0.05$ & $<0.05$ & 2 & - & $<0.05$ & $<0.05$ \\
\hline & Paraná & 144 & 693 & - & $>0.05$ & 297 & 58 & - & $>0.05$ \\
\hline & Uruguay & 154 & 1514 & 1325 & - & 577 & 1019 & 1244 & - \\
\hline & $\mathrm{KW}$ & \multicolumn{4}{|c|}{$H=73.2, H c=73.2,<\mathbf{0 . 0 5}$} & \multicolumn{4}{|c|}{$H=106.5, H c=106.5,<\mathbf{0 . 0 5}$} \\
\hline & $\mathrm{MN}$ & \multicolumn{4}{|c|}{$E p=108.7,<\mathbf{0 . 0 5}$} & \multicolumn{4}{|c|}{$E p=124.3,<\mathbf{0 . 0 5}$} \\
\hline \multirow{6}{*}{$\mathrm{PC} 2$} & Bermejo & - & $<0.05$ & $<0.05$ & $<0.05$ & - & $<0.05$ & $<0.05$ & $<0.05$ \\
\hline & Paraguay & 344 & - & $<0.05$ & $>0.05$ & 70 & - & $>0.05$ & $<0.05$ \\
\hline & Paraná & 9 & 660 & - & $<0.05$ & 12 & 1358 & - & $>0.05$ \\
\hline & Uruguay & 227 & 2640 & 381 & - & 0 & 1491 & 981 & - \\
\hline & $\mathrm{KW}$ & \multicolumn{4}{|c|}{$H=78.5, H c=78.5,<\mathbf{0 . 0 5}$} & \multicolumn{4}{|c|}{$H=75.3, H c=75.3,<\mathbf{0 . 0 5}$} \\
\hline & $\mathrm{MN}$ & \multicolumn{4}{|c|}{$E p=103.9,<\mathbf{0 . 0 5}$} & \multicolumn{4}{|c|}{$E p=130.3,<\mathbf{0 . 0 5}$} \\
\hline \multicolumn{10}{|c|}{ (DCA): } \\
\hline \multirow{6}{*}{ CA1 } & Bermejo & - & $<0.05$ & $<0.05$ & $<0.05$ & - & $<0.05$ & $<0.05$ & $<0.05$ \\
\hline & Paraguay & 0 & - & $<0.05$ & $>0.05$ & 0 & - & $<0.05$ & $>0.05$ \\
\hline & Paraná & 0 & 1828 & - & $<0.05$ & 18 & 690 & - & $<0.05$ \\
\hline & Uruguay & 0 & 2209 & 1311 & - & 0 & 2360 & 312 & - \\
\hline & $\mathrm{KW}$ & \multicolumn{4}{|c|}{$H=61.1, H c=61.1,<\mathbf{0 . 0 5}$} & \multicolumn{4}{|c|}{$H=91.9, H c=91.9,<\mathbf{0 . 0 5}$} \\
\hline & $\mathrm{MN}$ & \multicolumn{4}{|c|}{$E p=109.7,<\mathbf{0 . 0 5}$} & \multicolumn{4}{|c|}{$E p=118.8,<\mathbf{0 . 0 5}$} \\
\hline \multirow{6}{*}{ CA2 } & Bermejo & - & $>0.05$ & $<0.05$ & $<0.05$ & - & $<0.05$ & $<0.05$ & $<0.05$ \\
\hline & Paraguay & 593 & - & $<0.05$ & $>0.05$ & 466 & - & $<0.05$ & $<0.05$ \\
\hline & Paraná & 45 & 145 & - & $<0.05$ & 17 & 39 & - & $<0.05$ \\
\hline & Uruguay & 612 & 2110 & 153 & - & 308 & 695 & 487 & - \\
\hline & KW & \multicolumn{4}{|c|}{$H=99.3, H c=99.3,<\mathbf{0 . 0 5}$} & \multicolumn{4}{|c|}{$H=126.9, H c=126.9,<\mathbf{0 . 0 5}$} \\
\hline & $\mathrm{MN}$ & \multicolumn{4}{|c|}{$E p=100.8,<\mathbf{0 . 0 5}$} & \multicolumn{4}{|c|}{$E p=120.7,<\mathbf{0 . 0 5}$} \\
\hline
\end{tabular}



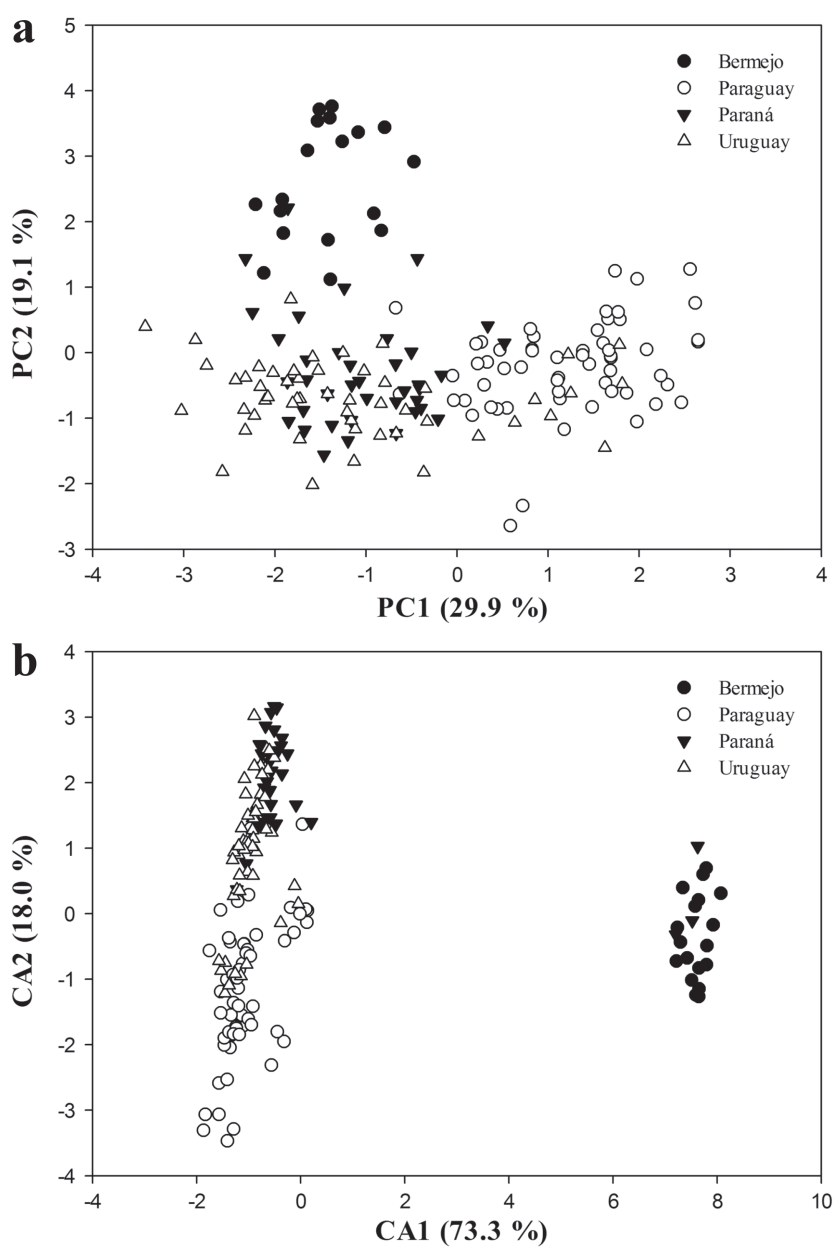

Fig. 3. Most discriminant axes obtained from the multivariate analyses of the square-root transformed meristic data of Moenkhausia bonita. a. principal component analysis; b. discriminant canonical analysis.

DCA on the adjusted meristic data revealed partial morphological differences among the groups (Fig. 3b). CA1 almost entirely discriminated the Bermejo group from the remaining groups except from some individuals of the Paraná group. Along CA2, the individuals of the Paraná group were separated from the majority of the individuals of the Paraguay group, but overlapped completely with the individuals of the Uruguay group. The highest loadings for these separations were the number of maxillary teeth $(0.05)$, scales below lateral line $(0.03)$, and teeth in the outer premaxillary row $(-0.02)$ in $\mathrm{CA} 1$; and the number of maxillary teeth (0.17), circumpeduncular scales (0.10), lateral line scales (-0.05), and gill rakers on the lower limb of the first gill arch (-0.03) in CA2. A full list of the meristic loadings can be found in $\mathbf{S 3}$ - Available only as online supplementary file accessed with the online version of the article at http://www.scielo.br/ni. The relative influence of the number of maxillary teeth, circumpeduncular scales, and scales below lateral line on the morphological discrimination was also partially confirmed by comparative box plots (Fig. 4). Conversely, the number of gill rakers of the first gill arch did not differentiate any groups in the box plots (Fig. 4d). a

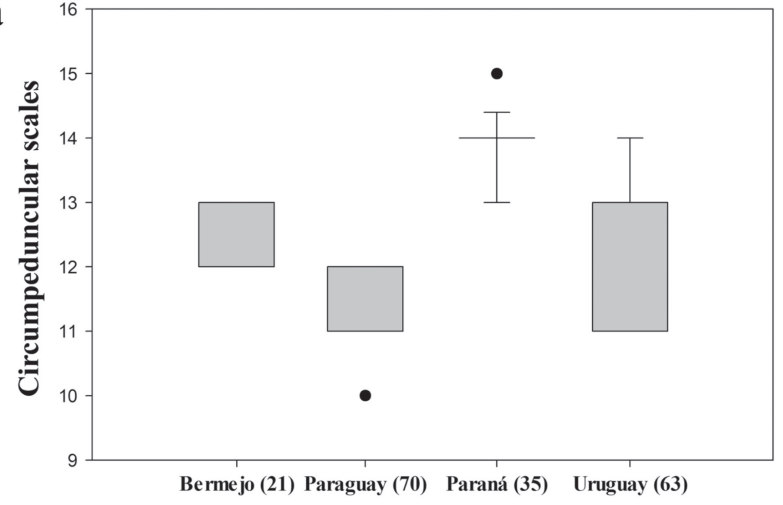

b

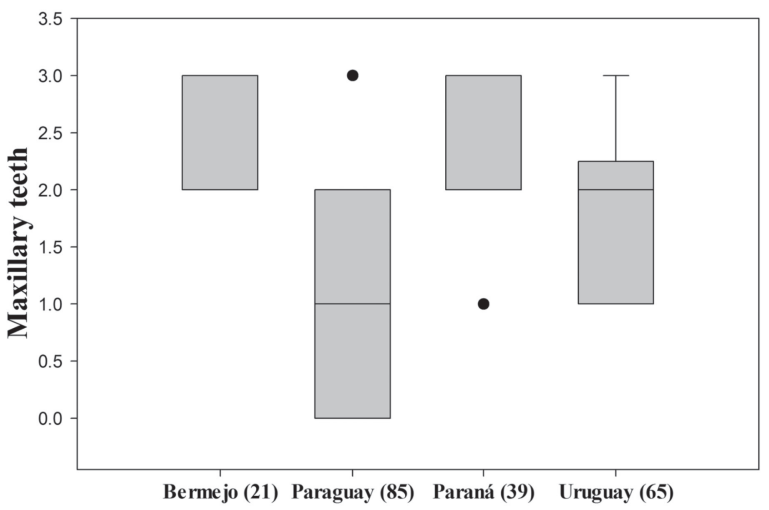

c

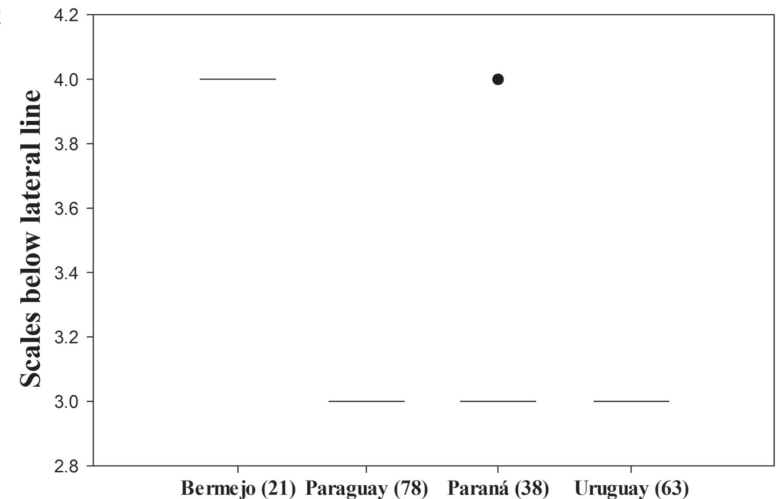

d

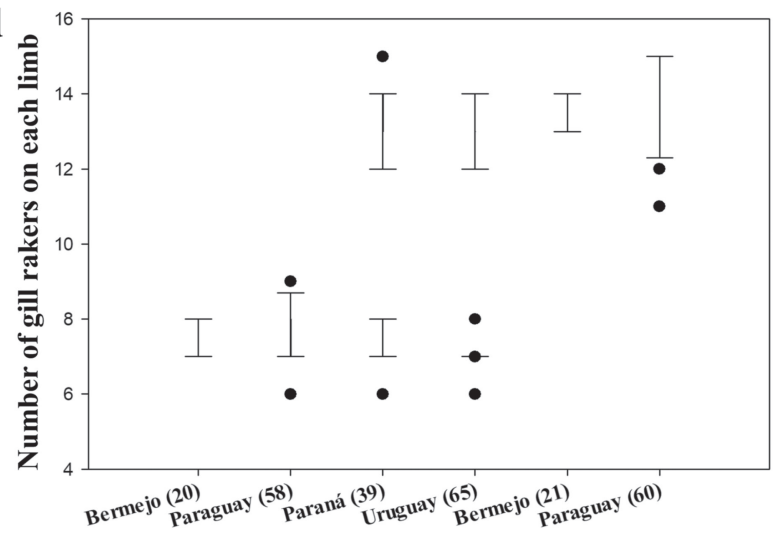

Fig. 4. Tukey box plots showing intraspecific variation of Moenkhausia bonita in the most informative counts found through the multivariate analyses. a. circumpeduncular scales; b. maxillary teeth; c. scales below the lateral line; d. number of gill rakers on each limb (upper vs. lower, in the bottom and top parts, respectively). Number of specimens in brackets. 
Tab. 5. Results of Kruskall-Wallis (KW) tests and Mann-whitney $(U)$ pairwise comparisons (based on the Bonferronicorrected $p$ values) of the resultant shape and meristic scores of principal component analysis (PCA) and discriminant canonical analysis (DCA). $U$ values: below diagonal; multivariate normality: $\mathrm{MN} ; p$ values are expressed as $<0.05$ or $>0.05$ (significant results in bold).

\begin{tabular}{|c|c|c|c|c|c|c|c|c|c|}
\hline & & \multicolumn{4}{|c|}{ Morphometric scores } & \multicolumn{4}{|c|}{ Meristic scores } \\
\hline & & Bermejo & Paraguay & Paraná & Uruguay & Bermejo & Paraguay & Paraná & Uruguay \\
\hline \multicolumn{10}{|c|}{$(\mathrm{PCA}):$} \\
\hline \multirow{6}{*}{ PC1 } & Bermejo & - & $<0.05$ & $<0.05$ & $<0.05$ & - & $<0.05$ & $>0.05$ & $>0.05$ \\
\hline & Paraguay & 169 & - & $<0.05$ & $<0.05$ & 2 & - & $<0.05$ & $<0.05$ \\
\hline & Paraná & 144 & 693 & - & $>0.05$ & 297 & 58 & - & $>0.05$ \\
\hline & Uruguay & 154 & 1514 & 1325 & - & 577 & 1019 & 1244 & - \\
\hline & $\mathrm{KW}$ & \multicolumn{4}{|c|}{$H=73.2, H c=73.2,<\mathbf{0 . 0 5}$} & \multicolumn{4}{|c|}{$H=106.5, H c=106.5,<\mathbf{0 . 0 5}$} \\
\hline & $\mathrm{MN}$ & \multicolumn{4}{|c|}{$E p=108.7,<\mathbf{0 . 0 5}$} & \multicolumn{4}{|c|}{$E p=124.3,<\mathbf{0 . 0 5}$} \\
\hline \multirow{6}{*}{$\mathrm{PC} 2$} & Bermejo & - & $<0.05$ & $<0.05$ & $<0.05$ & - & $<0.05$ & $<0.05$ & $<0.05$ \\
\hline & Paraguay & 344 & - & $<0.05$ & $>0.05$ & 70 & - & $>0.05$ & $<0.05$ \\
\hline & Paraná & 9 & 660 & - & $<0.05$ & 12 & 1358 & - & $>0.05$ \\
\hline & Uruguay & 227 & 2640 & 381 & - & 0 & 1491 & 981 & - \\
\hline & KW & \multicolumn{4}{|c|}{$H=78.5, H c=78.5,<\mathbf{0 . 0 5}$} & \multicolumn{4}{|c|}{$H=75.3, H c=75.3,<\mathbf{0 . 0 5}$} \\
\hline & $\mathrm{MN}$ & \multicolumn{4}{|c|}{$E p=103.9,<\mathbf{0 . 0 5}$} & \multicolumn{4}{|c|}{$E p=130.3,<\mathbf{0 . 0 5}$} \\
\hline \multicolumn{10}{|c|}{ (DCA): } \\
\hline \multirow{6}{*}{ CA1 } & Bermejo & - & $<0.05$ & $<0.05$ & $<0.05$ & - & $<0.05$ & $<0.05$ & $<0.05$ \\
\hline & Paraguay & 0 & - & $<0.05$ & $>0.05$ & 0 & - & $<0.05$ & $>0.05$ \\
\hline & Paraná & 0 & 1828 & - & $<0.05$ & 18 & 690 & - & $<0.05$ \\
\hline & Uruguay & 0 & 2209 & 1311 & - & 0 & 2360 & 312 & - \\
\hline & KW & \multicolumn{4}{|c|}{$H=61.1, H c=61.1,<\mathbf{0 . 0 5}$} & \multicolumn{4}{|c|}{$H=91.9, H c=91.9,<\mathbf{0 . 0 5}$} \\
\hline & $\mathrm{MN}$ & \multicolumn{4}{|c|}{$E p=109.7,<\mathbf{0 . 0 5}$} & \multicolumn{4}{|c|}{$E p=118.8,<\mathbf{0 . 0 5}$} \\
\hline \multirow{6}{*}{ CA2 } & Bermejo & - & $>0.05$ & $<0.05$ & $<0.05$ & - & $<0.05$ & $<0.05$ & $<0.05$ \\
\hline & Paraguay & 593 & - & $<0.05$ & $>0.05$ & 466 & - & $<0.05$ & $<0.05$ \\
\hline & Paraná & 45 & 145 & - & $<0.05$ & 17 & 39 & - & $<0.05$ \\
\hline & Uruguay & 612 & 2110 & 153 & - & 308 & 695 & 487 & - \\
\hline & KW & \multicolumn{4}{|c|}{$H=99.3, H c=99.3,<\mathbf{0 . 0 5}$} & \multicolumn{4}{|c|}{$H=126.9, H c=126.9,<\mathbf{0 . 0 5}$} \\
\hline & MN & \multicolumn{4}{|c|}{$E p=100.8,<\mathbf{0 . 0 5}$} & \multicolumn{4}{|c|}{$E p=120.7,<\mathbf{0 . 0 5}$} \\
\hline
\end{tabular}

In the confusion matrix from the DCA of the meristic data, $74.5 \%$ of all the examined individuals were correctly classified to their given group $(78.1 \%$ if the data were not jackknifed) (Tab. 3). The Bermejo (100\%) and Paraguay groups $(82.2 \%)$ had the highest frequency of correct classification. The Kruskal-Wallis tests revealed significant differences in the meristic scores in PC1 and PC2 (Tab. 4). Based on the post hoc pairwise comparisons, the differences were only statistically significant for the Paraguay group $v s$. the remaining groups on PC1, while on PC2 the group discrimination was significant in most cases except some comparisons involving the $\mathrm{Pa}$ raná, Paraguay, and Uruguay groups (Tab. 4). Regarding CA1 and CA2, statistically significant values were obtained from the Kruskal-Wallis tests and, consequently, the post hoc pairwise comparisons indicated significant differences among all the groups on both axes except between the Paraguay and Uruguay group in CA1 (Tab. 4). The Mantel test did not detect significant correlation betwe- en the morphometric and meristic distance matrices $(r=$ $0.06 ; p>0.05)$.

Sexual variation. Subtle sexual differences were found in pelvic-fin length as follows: Bermejo (19.0-21.9 \% SL; females: 16.6-19.5 \% SL), Paraná (males: 18.1-20.9 \% SL; females: 15.0-18.1 \% SL), and Uruguay (males: $18.6-20.1 \%$ SL; females: $15.8-18.3 \% \mathrm{SL}$ ). None of the meristic data were observed to be sexually dimorphic. In live specimens, two pigmentation patterns were observed. Some specimens have an orangish or reddish pigmentation on the anal, caudal, and dorsal fins, whereas other specimens have a pale yellowish pigmentation on these fins (Fig. 5). As population memberships did not seem to structure this variation, we hypothesize that it represents sexual variation in which males are characterized by the orangish or reddish fins and females are characterized by the yellowish fins, but we did not confirm this conjecture by gonadal examination. This coloration is not visible after preservation (Fig. 6). No bony hooks were observed in adult male specimens. 


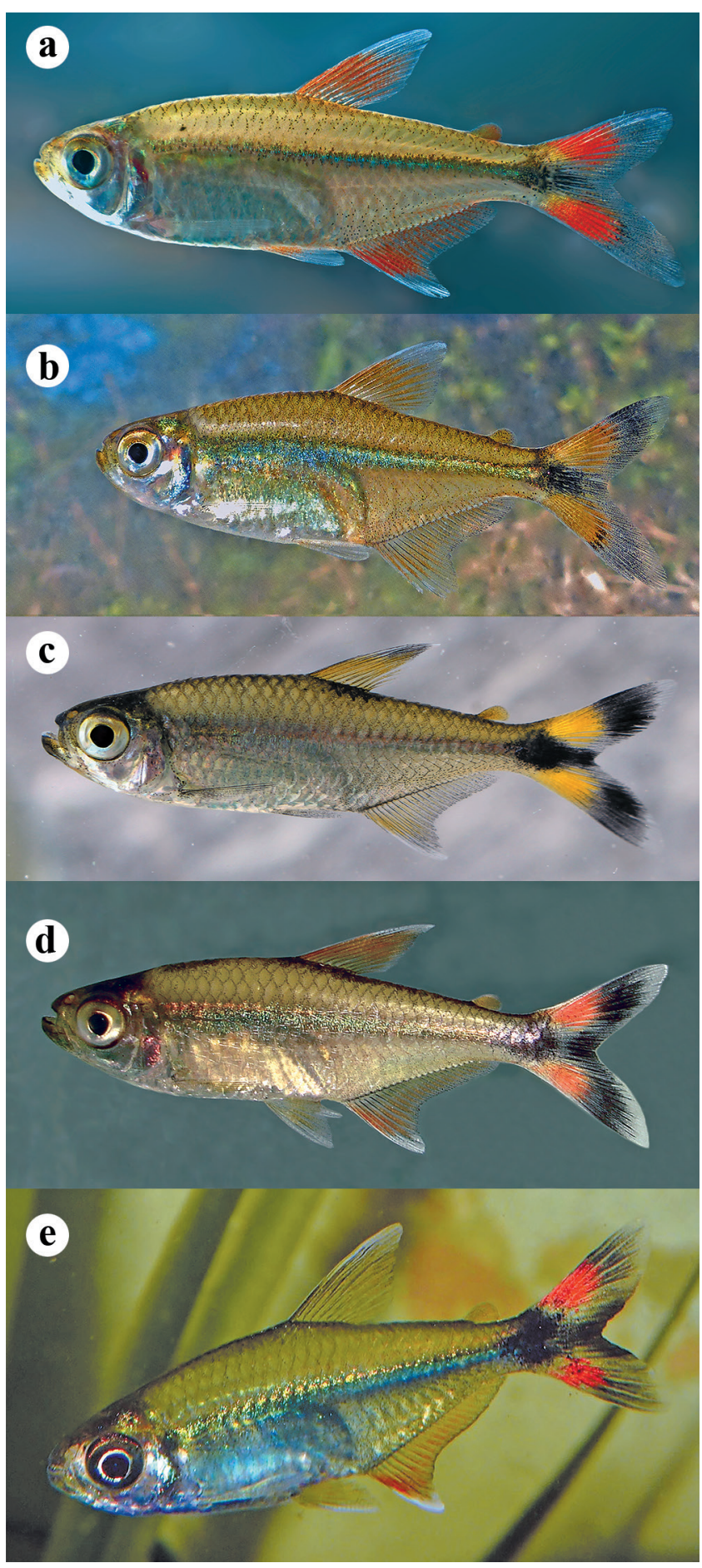

Fig. 5. Coloration pattern in live of Moenkhausia bonita from different geographic basins. a. CI-FML 7272, unnamed stream between Blanco and Bermejo rivers, Salta, Argentina (by Felipe Alonso); b. CI-FML 5351, El Oculto stream, Bermejo basin, Orán, Salta, Argentina (by Felipe Alonso); c. uncatalogued specimen, Lagoon or Bahia in BR362 next to rio Paraguay in Corumbá, Brazil; d. uncatalogued specimen, Mburucuyá National Park, Paraná basin, Corrientes, Argentina (by Liliana Ciotek); e. uncatalogued specimen, Lagoon at rio Riachuelo, Paraná basin, San Luis del Palmar, Argentina (by Miguel Albarenga).
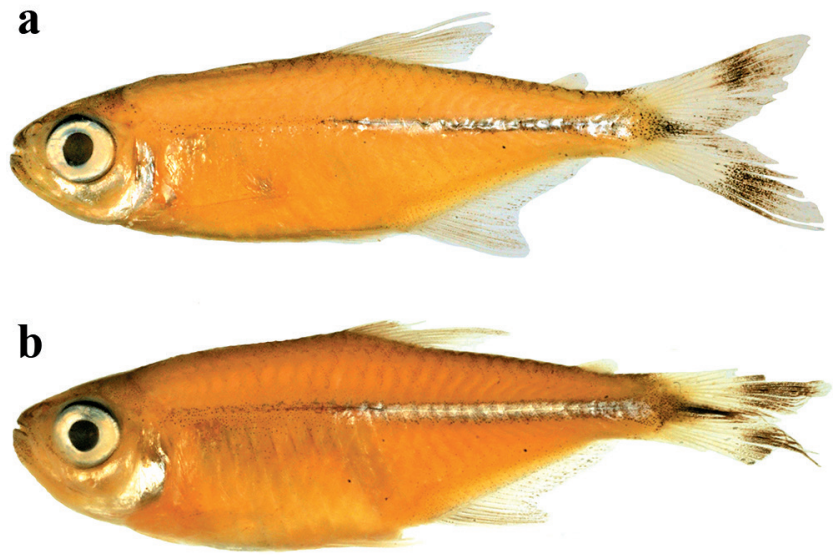

Fig. 6. Coloration pattern in alcohol-preserved specimens of Moenkhausia bonita. a. MLP 11244, 31.9 mm SL, Uruguay basin; b. MLP 11241, 33.1 mm SL, Paraná basin.

\section{Discussion}

Intraspecific morphological variation is often attributed to differential adaptations to diverse habitats. Thus, its study helps to understand the diversity of life and to appraise whether morphological variability results from selection by ecological and environmental factors or biogeographic history (e.g. vicariance, dispersal or genealogical history) (Norris, Douglas, 1992; Adams et al., 2004; D'Anatro, Loureiro, 2005; Albert, Reis, 2011; Lazzarotto et al., 2017). Comparisons carried out herein revealed subtle morphological differences among the studied groups in morphometric and meristic data but not in coloration patterns (Fig. 5). These intraspecific differences were statistically significant in most multivariate analyses. However, the samples from the rio Paraguay basin could not be significantly discriminated from those in the rio Uruguay basin using either morphometric or meristic data (Tab. 4). The samples from the Bermejo basin, which is geographically the most distant group, were almost perfectly distinguished across the multivariate comparisons, especially through DCA (Figs. 2-3). This group also was partly distinguished from the other groups by the number of scales below the lateral line, which is always 4 in specimens from the Bermejo, and either 3 or 4 (mode $=3$ ) in the remaining groups. The distinctiveness of the Bermejo specimens may indicate the existence of a cryptic species within the present concept of $M$. bonita, but could also simply characterize relatively high phenotypic variability within a widespread species. Given that we found a great overlap among the ranges of the morphometric and meristic data for the groups (see Tabs. 1,4) and did not detect distinctive osteological differences in the c\&s specimens that could be associated with group memberships, we considered the observed variation to be of a magnitude typical of population-level differences within a single species. Despite its almost complete ability to diagnose the Bermejo population from the other groups, the slight variation in the number of scales below the lateral line is not enough by itself 
to treat the Bermejo population as a different nominal species. Additionally, the morphological distinction found for the Bermejo group may result from a lack of morphologically intermediate specimens from downstream in the river basin. In any case, performing further DNA comparisons would be useful to confirm or not whether the morphological patterns found are corresponding to population- or species-level variation.

The morphometric multivariate comparisons performed in the present study revealed that the discrimination among the groups was mostly driven by variations in the caudal peduncle length, distance between dorsal-fin origin to caudal-fin base, snout length, and upper jaw length in both PCA and DCA (except in CA3 for the caudal peduncle length, see $\mathbf{S 3}$ - Available only as online supplementary file accessed with the online version of the article at http://www.scielo.br/ ni). Such variation in body and head shapes of fish populations may be influenced by differences in predation (Burns et al., 2009; Araújo et al., 2014), diet (Hegrenes, 2001), local habit (Langerhans et al., 2003; Sidlauskas et al., 2006; Webster et al., 2011), geomorphology (physical and/or chemical features) or sub-basins (Lowe-McConnell, 1999), and genetic divergence or phenotypic plasticity or a combination of those factors (Svanbäck, Eklöv, 2006; Elmer et al., 2010; Zamudio et al., 2016). Some intraspecific studies on characid species have pointed out that morphological differentiation among populations or groups can be related to environmental, heterochronic, or geographic factors (Román-Valencia et al., 2009; Ornelas-García et al., 2014; Aguirre et al., 2016; Marinho, Langeani, 2016; Vanegas-Ríos, 2016; Lazzarotto et al., 2017).

Ecological data on M. bonita are not available for any of the basins and are virtually non-existent in the literature. Therefore, it is not possible to determine which potential ecological variables drive the observed morphological patterns. However, we hypothesize that the geographic or spatial distance (e.g. latitudinal and longitudinal variations, see Chown, Klok, 2003; Blanck, Lamouroux, 2007) among the groups and the distinctive habitat characteristics may influence variation in body and mouth shapes. Langerhans et al. (2003) found that the magnitude of morphological differences tends to increase with increasing spatial distance between locations, as part of a population comparison between two Neotropical fish species. The Bermejo, Paraguay, Paraná, and Uruguay river basins are characterized by relatively different environmental conditions that become more distinctive in areas distant from the confluences zones. Those differences are regulated by geophysical and chemical factors such as flow regime, conductivity, dissolved oxygen, and suspended solids, among others (Bonetto, 1986; Persia, Neiff, 1986; Bonetto, 2006; Quirós et al. 2007). Fluctuations within this kind of variables have been proven to impact on the morphological heterogeneity in other fish species [Langerhans et al., 2003: Bryconops caudomaculatus (Günther), Biotodoma wavrini (Gosse); Langerhans et al., 2007: African cyprinid Enteromius neumayeri (Fischer); Garduño-Paz et al., 2010: Gasterosteus aculeatus Linnaeus]. Whether the observed variations result from genetic differences, phenotypic plastic- ity, or both is unknown. Such factors should be further tested in a more comprehensive study including DNA, morphological, and ecological data of each population.

With regard to the meristic variables analyzed, the number of lateral line scales, scales below lateral line, circumpeduncular scales and maxillary teeth were the variables that best differentiated groups (but not along all the plotted axes, see S3 - Available only as online supplementary file accessed with the online version of the article at http://www. scielo.br/ni). In several studies, meristic variations among population have been hypothesized to be associated with genetic and/or geographic factors (Holčík, Jedlička, 1994; Yamahira et al., 2006; Blanck, Lamouroux, 2007; Bahri-Sfar, Hassine, 2009).

Unlike $M$. bonita, most characid species and some of its congeners are easily sexed by the presence/absence of bony hooks on fin rays, different colorations in alcohol-preserved specimens, glandular structures, and/or modified scales and fins (Vari, Harold, 2001; Malabarba, Weitzman, 2003; Bertaco, Malabarba, 2010; Benine et al., 2009; Menezes, Weitzman, 2009; Marinho, Langeani, 2016; Vanegas-Ríos, 2016). Sexual dimorphism in $M$. bonita is much subtler. Based on specimens from the Paraguay basin, Benine et al. (2004) described $M$. bonita with two sexually dimorphic measurements: pelvic-fin length $($ males $=18.9-21.6 \% \mathrm{SL}, \mathrm{n}=8 \mathrm{vs}$. females/juveniles $=16.1-18.5 \% \mathrm{SL}, \mathrm{n}=12)$ and dorsal-fin length (males $=32.4-34.1 \% \mathrm{SL}, \mathrm{n}=8 v \mathrm{~s}$. females/juveniles $=29.4-31.2 \% \mathrm{SL}, \mathrm{n}=12$ ). We also detected a subtle sexual difference in the pelvic-fin length (males: $18.6-21.9 \% \mathrm{SL}$, $\mathrm{n}=36$; females: $15.0-19.5 \% \mathrm{SL}, \mathrm{n}=27$, in total) but not in the dorsal-fin length, perhaps because we analyzed a different sample of individuals than did Benine et al. (2004). No meristic variables were found to be associated with sexual dimorphism. Although significant samples of adult males were not available to test any possible influence of the sexual dimorphism on the intraspecific variation of $M$. bonita, specimens of both sexes were represented in the multivariate comparisons. The coloration on the anal, caudal, and dorsal fins observed in live specimens of $M$. bonita, which is associated with sex (Fig. 5: orangish or reddish in male $v s$. pale yellowish in female), were not reported in the original description (Benine et al., 2004). This color variation, which is known as sexual dichromatism and often appears only during reproductive seasons, is present in many species of Characidae (Pastana et al., 2017).

The congeners most similar to $M$. bonita are $M$. intermedia and $M$. dichroura. It is differentiated from $M$. intermedia and $M$. dichroura by fewer total gill rakers (6-8 + 11-15 vs. 9-12 + 18-22) (Benine et al., 2004; Britzke, 2011). Additionally, based on the character matrix of Benine (2004), M. intermedia lacks dorsal laminar expansions on the pleural ribs, which are present in $M$. bonita and $M$. dichroura (personal observation, JMM). According to Benine et al. (2004), M. bonita closely resembles some species of Hemigrammus in terms of body shape and pigmentation. However, the Hemigrammus species are characterized by an incomplete lateral 
line, which is complete in M. bonita. Benine et al. (2004) discussed that, although Hemigrammus marginatus Ellis resembles $M$. bonita by sharing a black midlateral stripe and a caudal fin bordered with dark pigmentation, it lacks the lozenge-shaped blotch on the caudal peduncle that characterizes $M$. bonita.

Distributional comments on $M$. bonita and $M$. intermedia. Previously, only three species of Moenkhausia have been recorded in Argentina: $M$. dichroura, $M$. intermedia, and $M$. sanctaefilomenae (Ringuelet et al., 1967; Mirande, Koerber, 2015; Fricke et al., 2019) (the potential occurrence of M. australe and those known records of $M$. sanctafilomenae in Argentina seem to need further revision, see Reia, 2018). Our results confirm the presence of $M$. bonita in this country and revealed that it occupies a considerably larger geographic range in the rio de la Plata basin than has been reported (Benine et al., 2004). Within Moenkhausia, other species have also been recognized as widely distributed (Lima et al., 2003; Benine et al., 2009; Britzke, 2011; Oliveira, Marinho, 2016; Marinho, Langeani, 2010, 2016; Soares et al., 2017): M. abyss Oliveira \& Marinho, M. collettii (Steindachner), M. dichroura, M. intermedia, M. jamesi Eigenmann, M. lepidura, M. megalops, M. mikia Marinho \& Langeani, and M. oligolepis.

It is worth of mentioning that the construction of the Itaípu dam may explain the occurrence of $M$. bonita in the upper Paraná floodplain. The presence of this dam, which is located to $150 \mathrm{~km}$ downstream from the Sete Quedas waterfall, and the later construction of the Piracema channel brought together part of the lower Paraná with the upper Paraná, modified some fish distributions and increased the number of species in the upper Paraná (Agostinho, Julio Jr, 1999; Langeani et al., 2007; Makrakis et al., 2007; Julio-Junior et al., 2009). The occurrence of $M$. bonita in the lower Paraná basin can be easily explained by the confluence zone with the rio Paraguay, which is a floodplain in which the ichthyofauna of both rivers mix (Bonetto, 1994).

After examining an extensive sample of specimens from major collections in Argentina, we concluded that previous records of $M$. intermedia or $M$. cf. intermedia in Argentina most probably correspond to M. bonita (Ringuelet et al., 1967; Lopez et al., 2003; Liotta, 2005; Mirande, Aguilera, 2009; Mirande, 2010; Mirande, Koerber, 2015). After Tortonese (1942), who proposed the first record of $M$. intermedia in Argentina, this species has been mainly recorded based on data compilations instead of specimen examination (Ringuelet et al., 1967; Lopez et al., 2003; Liotta, 2005), which, in part, has led to a misuse of the species name for more than 60 years. Tortonese (1942) described in detail a large sample of specimens of $M$. intermedia from " $S$. Lorenzo. Argentina" (presumably from Salta). JMM, who has sampled the freshwater fish fauna from northwest region in Argentina, has not collected specimens of Moenkhausia in that area other than those identified by us as M. bonita. Furthermore, based on Tortonese's description, we found that his samples of $M$. intermedia are morphologically similar to specimens of $M$. bonita examined herein. Although we have not examined all the specimens that have been used to support the occurrence of $M$. intermedia in Argentina, we expect that all unexamined specimens correspond to M. bonita, because since Ringuelet et al. (1967) only one morphotype of $M$. intermedia has been recognized by other ichthyologists in Argentina (personal communication of M. M. Azpelicueta, J. Casciotta, and A. Almirón, March 2018). Finally, the incorrect identification of $M$. intermedia in Argentina is not unexpected, because its occurrence in the rio de la Plata basin, especially in the Paraguay and Paraná river basins, has already been questioned (Benine, 2004; Britzke, 2011).

Based on our results and previous records (Lima et al., 2013; Queiroz et al., 2013), Moenkhausia bonita occurs in the La Plata and Madeira river basins. As such, it provides an interesting opportunity to study biogeographic patterns and historical connections among large basins. Despite the fact that one of us (RB) identified one lot from rio Guaporé (Amazon basin) in Brazil (MZUSP 73994) as M. bonita, which agrees with previous records for the species, representative specimens were not available and we could not include them in the present study. This issue is a pending task under ongoing study.

Material examined: Moenkhausia bonita. Amazon basin: MZUSP 73994, 8, 20.1-39.9 mm SL (not measured). Bermejo basin: CI-FML 3321, 42, 26.4-34.5 mm SL; CI-FML 3417, 3 c\&s, 31.5-35.4 mm SL; CI-FML 5351, 3, 26.5-31.4 mm SL; CI-FML 7267, 20, $20.4-$ $31.5 \mathrm{~mm}$ SL; CI-FML 7155 (former LBP 3222), 8 (1 c\&s $30 \mathrm{~mm}$ SL), 26.1-45.1 mm SL; CI-FML 7268, 2, 32.9-35.8 mm SL; CI-FML 7269, 7, 28.2-30.8 mm SL; CI-FML 7270, 19, 24.5-32.1 mm SL; CI-FML 7271, 2, 28.4-30.2 mm SL; CI-FML 7272, 32, 22.3-40.2 mm SL; CI-FML 7273, 4, 17.9-36.2 mm SL. Paraguay basin: LBP 3222 , 32, 14.9-33.2 mm SL; LBP 3234, 1, 30.1 mm SL; LBP 3740, 3, 17.325.0 mm SL; LBP 3783, 20, 19.4-39.9 mm SL; LBP 4737, 1, 22.8 mm SL; LBP 5644, 6, 39.0-49.4 mm SL; LBP 5796, 5, 25.9-34.5 mm SL; LBP 9013, 8, 27.5-33.4 mm SL; MLP 8790, 5, 22.7-28.8 mm SL; MLP 8821, 1, 23.2 mm SL; NUP 2140, 3, 21.9-28.0 mm SL; NUP 8699, 7, 26.2, 36.4 mm SL; NUP 8702, 1, 39.4 mm SL; NUP 8703; 3, 28.8-32.7 mm SL. Paraná basin: LBP 5242, 58, 23.5-35.0 mm SL; LBP 9626, 22, 19.7-34.7 mm SL; LBP 9699, 10, 20.6-38.1 mm SL; MACN 7734, 14, 19.0-31.7 mm SL; MACN 7699, 10, 20.7-32.2 mm SL; MACN 8637, 4, 30.2-33.1 mm SL; MACN 11295, 17, 16.4 $37.0 \mathrm{~mm}$ SL; MACN 12360, 1, $41.1 \mathrm{~mm}$ SL; MLP 11241, 24, 24.6$33.1 \mathrm{~mm}$ SL (4 c\&s, 27.5-32.3 mm SL); MLP 11242, 2, 34.5-34.5 mm SL; MLP 8415, 15, 24.6-32.3 mm SL; MLP 10198, 18, 24.237.5 mm SL; MLP 10134, 15, 21.8-29.6 mm SL; MZUSP 10248, 7, 25.4-39.94 mm SL. Uruguay basin: MACN 12361, 2, 32.8-33.1 mm SL; MCP 26804, 10, 28.6-34.7 mm SL; MCP 27493, 10, 29.2-37.0 mm SL; MLP 11243, 35, 21.8-34.9 mm SL; MLP 11244, 15, 25.4$33.4 \mathrm{~mm}$ SL (5 c\&s, 28.3-33.4 mm SL). Moenkhausia dichroura. Paraguay basin: LBP 26, 33, 24.1-55.4 mm SL; LBP 3760, 3, 55.664.1 mm SL; LBP 5101, 32, 24.3-41.5 mm SL; MZUSP 48536, 10 , 34.4-50.7 mm SL; MZUSP 54034, 7, 28.1-35.5 mm SL; NUP 125, 9, 57.5-69.8 mm SL; NUP 8744, 5, 51.0-70.0 mm SL; NUP8740, 10, 53.8-66.8 mm SL; NUP 8751, 5, 42.7-51.7 mm SL. Paraná ba- 
sin: MACN 7678, 9, 37.1-45.1 mm SL; MACN 7736, 7, 51.4-53.8 mm SL; MACN 10512, 1, 55.5 mm SL; MACN 11031, 1, $42.1 \mathrm{~mm}$ SL; MACN 12359, 1, 52.7 mm SL; MACN 12362, 4, 45.0-50.1 mm SL; MACN 12363, 5, 49.3-55.1 mm SL (1 c\&s 49.3 mm SL); MLP 9000, 9, 48.4-55.7 mm SL; MLP 9289, 26, 31.5-42.8 mm SL; MLP 9377, 7, 50.4-56.5 mm SL. Moenkhausia intermedia. Amazon basin: LBP 4050, 5, 23.6-49.6 mm SL; LBP 4060, 1, 39.3 mm SL; LBP 4091, 2, 50.0-57.5 mm SL; MCZ 20762, 1 (photograph), 47.5 mm SL, syntype of Moenkhausia dichrourus intermedius; MZUSP 26134, 2, 39.1-43.6 mm SL; MZUSP 26375, 3, 37.5-39.76 mm SL; MZUSP 89280, 4, 38.1-44.3 mm SL; MZUSP 89375, 10, 44.0-51.1 mm SL; MZUSP 50141, 33, 35.1-45.2 mm SL; Moenkhausia aff. intermedia. AUM 27704, 1, $45.3 \mathrm{~mm}$ SL. Moenkhausia sanctaefilomenae. MACN 11193, 6, 25.2-30.7 mm SL.

\section{Acknowledgments}

We thank the following individuals and institutions for the assistance and support: Guillermo Terán and Gastón Aguilera (CI-FML); Cláudio Oliveira (LBP); Adriana Almirón, Mercedes Azpelicueta, Jorge Casciotta, and Diego Nadalin (MLP); Cláudio Zawadzki and Carla Pavanelli (NUP); Gustavo Chiaramonte and Ricardo Ferriz (MACN); Karsten Hartel (MCZ); Carlos Lucena and Zilda M. de Lucena (MCP); H. Britski, J. L. Figueiredo, and Osvaldo Oyakawa (MZUSP). We are indebted to Ignasio García and A. Paracampo (ILPLA), who provided fish samples from Corrientes. We are grateful to Felipe Alonso (IBIGEO-CONICET), Heriberto Gimenes, Liliana Ciotek, and Miguel Albarenga, who provided photos in life of Moenkhausia bonita, and to Bruno García (MLP), who helped with photographs of alcohol-preserved specimens. JAVR is grateful for the permanent support received from the CONICET. Additional financial support was received through subsidies PICT-2011-0992 (JMM), PICT-2014-2357 (A. Cione and M. Azpelicueta), and PIP-0301 (JMM). RB is financially supported by CNPq (Proc. 132968/2009-6) and FAPESP (Proc. 2011/00269-4). Brian Sidlauskas, Manoela M. F. Marinho, Rafaela P. Ota, and Ricardo C. Benine provided incredibly helpful comments and corrections that have enriched this paper.

\section{References}

Adams DC, Rohlf FJ, Slice DE. Geometric morphometrics: Ten years of progress following the 'revolution'. Ital J Zool. 2004; 71(1):5-16.

Agostinho AA, Julio Jr HF. Peixes da bacia do Alto rio Paraná. In: Lowe-McConnell RH, editor. Estudos ecológicos de comunidades de peixes tropicais. São Paulo: Edusp; 1999. p. 374-400.

Aguirre WE, Navarrete R, Malato G, Calle P, Loh MK, Vital WF, et al. Body shape variation and population Genetic structure of Rhoadsia altipinna (Characidae: Rhoadsiinae) in Southwestern Ecuador. Copeia. 2016; 104(2):554-70.

Albert JS, Petry P, Reis RE. Major biogeographic and phylogenetic patterns. In: Albert JS, Reis RE, editors. Historical biogeography of Neotropical freshwater fishes. First ed. California: University of California Press; 2011. p.21-57.
Albert JS, Reis RE, editors. Historical biogeography of Neotropical freshwater fishes. First ed. California: University of California Press; 2011.

Araújo MS, Perez SI, Magazoni MJC, Petry AC. Body size and allometric shape variation in the molly Poecilia vivipara along a gradient of salinity and predation. BMC Evol Biol. 2014; 14(1):251.

Bahri-Sfar L, Hassine KBO. Clinal variations of discriminative meristic characters of sea bass, Dicentrarchus labrax (Moronidae, Perciformes) populations on Tunisian coasts. Cybium. 2009; 33(3):211-18.

Benine RC. Análise filogenética do gênero Moenkhausia (Characiformes: Characidae) com uma revisão dos táxons do alto Rio Paraná [PhD Thesis]. São Paulo: Universidade Estadual Paulista; 2004.

Benine RC, Castro RMC, Sabino J. Moenkhausia bonita: a new small characin fish from the rio Paraguay basin, southwestern Brazil (Characiformes: Characidae). Copeia. 2004; 2004(1):68-73.

Benine RC, Mariguela TC, Oliveira C. New species of Moenkhausia Eigenmann, 1903 (Characiformes: Characidae) with comments on the Moenkhausia oligolepis species complex. Neotrop Ichthyol. 2009; 7(2):161-68.

Bertaco VA, Malabarba LR. A review of the Cis-Andean species of Hemibrycon Günther (Teleostei: Characiformes: Characidae: Stevardiinae), with description of two new species. Neotrop Ichthyol. 2010; 8(4):737-70.

Blanck A, Lamourroux N. Large-scale intraspecific variation in life-history traits of European freshwater fish. J Biogeogr. 2007; 34(5):862-75.

Bonetto AA. The Paraná River system. In: Davies BR, Walker KF, editors. The ecology of river systems. The Netherlands: Springer Netherlands; 1986. p. 541-98.

Bonetto AA. Austral rivers of South America. In: Margalef R, editor. Limnology now: a paradigm of planetary problems. Amsterdam: Elsevier Science; 1994. p. 425-72.

Bonetto AA. Southern south American streams and rivers. In: Cushing CE, Cummins KW, Minshall GW, editors. River and stream ecosystems of the world. Berkeley: University of California Press; 2006. p. 257-293.

Britski HA, Silimon KZS. Descrição de uma nova espécie de Moenkhausia da bacia do rio Paraguai (Teleostei: Ostariophysi: Characiformes). Comun Mus Cienc Tecnol Pucrs Ser Zool. 2001; 14(2):111-20.

Britzke R. Revisão taxonômica do grupo Moenkhausia dichroura (Kner, 1858) (Characiformes: Characidae) [Msc Dissertation]. Botucatu: Universidade Estadual Paulista; 2011.

Britzke R, Troy WP, Oliveira C, Benine RC. Description of a new species of Moenkhausia Eigenmann (Characiformes: Characidae) from the upper Paraguay basin, Central Brazil, with comments on its phylogenetic relationships. Neotrop Ichthyol. 2018; 16(2):e170086.

Burnaby TP. Growth-invariant discriminant functions and generalized Distances. Biometrics. 1966; 22(1):96-110.

Burns JG, Di Nardo P, Rood FH. The role of predation in variation in body shape in guppies Poecilia reticulata: a comparison of field and common garden phenotypes. J Fish Biol. 2009; 75(6):1144-57. 
Castro RJ, Vizzotto PC. Fishes of the Vermelho River, São Lourenço River basin, Mato Grosso State, Brazil. Check List. 2013; 9(1):1-3.

Cattel RB. The scree test for the number of factors. Multivariate Behav Res. 1966; 1(2):245-76.

Chown SL, Klok CJ. Altitudinal body size clines: latitudinal effects associated with changing seasonality. Ecography. 2003; 26(4):445-55.

Cordeiro LM, Borghezan R, Trajano E. Subterranean biodiversity in the Serra da Bodoquena karst area, Paraguay river basin, Mato Grosso do Sul, Southwestern Brazil. Biota Neotrop. 2014; 14(3):e201400114.

D'Anatro A, Loureiro M. Geographic variation in Austrolebias luteoflamulatus Vaz-Ferreira, Sierra \& Scaglia (Cyprinodontiformes, Rivulidae). J Fish Biol. 2005; 67(3):849-65.

Doornik JA, Hansen H. An omnibus test for univariate and multivariate normality. Oxford Bull Econ Statist. 2008; 70(1):927-39.

Eigenmann CH. The American Characidae-Part I. Memoirs Mus Comp Zool. 1917; 43:1-102.

Elmer KR, Kusche H, Lehtonen TK, Meyer A. Local variation and parallel evolution: morphological and genetic diversity across a species complex of neotropical crater lake cichlid fishes. Philos Trans R Soc Lond B Biol Sci. 2010; 365(1547):1763-82.

Fink WL, Weitzman SH. The so-called Cheirodontin fishes of Central America with descriptions of two new species (Pisces: Characidae). Washington (DC): Smithonian Institution Press; 1974. (Smithsonian Contribution to Zoology; No. 172).

Fricke R, Eschmeyer WN, Var del Laan R, editors. Eschmeyer's catalog of fishes: genera, species, references [Internet]. San Francisco: California Academy of Natural Sciences; 2019 [updated 2019 Jan 2 cited 2019 Jan 10]. Available from: http:// researcharchive.calacademy.org/research/ichthyology/catalog/ fishcatmain.asp

Frontier S. Etude de la dècroissance des valeurs propres dans une analyse en composantes principales: comparaison avec le modèle du bâton brisé. J Exp Mar Biol Ecol. 1976; 25(1):6775.

García-Vázquez D, Ribera I. The origin of widespread species in a poor dispersing lineage (diving beetle genus Deronectes). PeerJ. 2016; 4:e2514.

Garduño-Paz MV, Couderc S, Adams CE. Habitat complexity modulates phenotype expression through developmental plasticity in the threespine stickleback. Biol J Linn Soc. 2010; 100(2):407-13.

Gaston KJ. The structure and dynamics of geographic ranges. New York: Oxford University Press; 2003.

Hair Jr JF, Black WC, Babin BJ, Anderson RE. Multivariate data analysis: a global perpective. 7th ed. Upper Saddle River, N.J.: Pearson; 2010.

Hammer O, Harper DAT, Ryan PD. PAST: Paleontological statistics software package for education and data analysis. Palaeontol Electronica [serial on the Internet]. 2001; 4(1):1-9. Available from: http://palaeo-electronica.org/2001_1/past/issue1_01.htm

Hegrenes S. Diet-induced phenotypic plasticity of feeding morphology in the orangespotted sunfish, Lepomis humilis. Ecol Freshw Fish. 2001; 10(1):35-42.
Holčík J, Jedlička L. Geographical variation of some taxonomically important characters in fishes: the case of the bitterling Rhodeus sericeus. Environ Biol Fishes. 1994; 41(1-4):147-70.

Humphries JM, Bookstein FL, Chernoff B, Smith GR, Elder RL, Poss SG. Multivariate discrimination by shape in relation to size. Syst Biol. 1981; 30(3):291-308.

Huxley JS. Problems of relative growth. New York: The Dial Press; 1932.

Julio-Junior HF, Dei Tós C, Agostinho AA, Pavanelli CS. A massive invasion of fish species after eliminating a natural barrier in the upper rio Paraná basin. Neotrop Ichthyol. 2009; 7(4):709-18.

Kilmer JT, Rodríguez RL. Ordinary least squares (OLS) regression is indicated for studies of allometry. J Evol Biol. 2017; 30(1):412. DOI 10.1111/jeb.12986

Klingenberg CP. Multivariate Allometry. In: Marcus LF, Corti M, Loy A, Naylor GJP, Slice DE, editors. Advances in Morphometrics. Boston, MA: Springer US; 1996. p. 23-49.

Langeani F, Castro RMC, Oyakawa OT, Shibatta OA, Pavanelli CS, Casatti L. Diversidade da ictiofauna do Alto Rio Paraná: composição atual e perspectivas futuras. Biota Neotrop. 2007; 7(3):181-97.

Langerhans RB, Chapman LJ, Dewitt TJ. Complex phenotypeenvironment associations revealed in an East African cyprinid. J Evol Biol. 2007; 20(3):1171-81. DOI 10.1111/j.14209101.2007.01282.x

Langerhans RB, Layman CA, Langerhans AK, DeWitt TJ. Habitat associated morphological divergence in two Neotropical fish species. Biol J Linn Soc. 2003; 80(4):689-98.

Lawing AM, Meik JM, Schargel WE. Coding meristic characters for phylogenetic analysis: a comparison of step-matrix gapweighting and generalized frequency coding. Syst Biol. 2008; 57(1):167-73.

Lazzarotto H, Barros T, Louvise J, Caramaschi EP. Morphological variation among populations of Hemigrammus coeruleus (Characiformes: Characidae) in a Negro River tributary, Brazilian Amazon. Neotrop Ichthyol. 2017; 15(1):e160152.

Lima FCT, Malabarba LR, Buckup PA, Pezzi da Silva JF, Vari RP, Harold A, et al. Genera incertae sedis in Characidae. In: Reis RE, Kullander SO, Ferraris CJ, Jr., organizers. Check list of the freshwater fishes of South and Central America. Porto Alegre: EDIPUCRS; 2003. p.106-69.

Lima FCT, Pires THS, Ohara WM, Jerep FC, Carvalho FR, Marinho MMF, Zuanon J. Characidae. In: Queiroz LJ, Torrente-Vilara G, Ohara WM, Pires THS, Zuanon J, Dória CRC, orgs. Peixes do rio Madeira Vol. 1. First Edition. São Paulo: Dialeto Latin American Documentary; 2013. p. 213-395.

Liotta J. Distribución geográfica de los peces de aguas continentales de la República Argentina. La Plata: FCNYM, Coperative Chilavert Artes Gráficas; 2005. (Probiota, Serie documentos; No. 3).

Lomolino MV, Riddle BR, Whittaker RJ, Brown JH. Biogeography. 4th Ed. Sunderland: Sinauer Associates; 2010.

Lopez HL, Miquelarena AM, Menni RC. Lista comentada de los peces continentales de la Argentina. La Plata: PublicArt; 2003. (Probiota, Serie Técnica y Didáctica; No. 5). 
Lowe-McConnell RH. Estudos ecológicos de comunidades de peixes tropicais. São Paulo: EDUSP; 1999.

Malabarba LR, Weitzman SH. Description of new genus with six new species from southern Brazil, Uruguay and Argentina, with a discussion of a putative characid clade (Teleostei: Characiformes: Characidae). Comun Mus Ciên Tecnol PUCRS, Sér Zool 2003; 16(1):67-151.

Makrakis S, Gomes LC, Makrakis MC, Fernandez DR, Pavanelli CS. The Canal da Piracema at Itaipu Dam as a fish pass system. Neotrop Ichthyol. 2007; 5(2):185-95.

Marcus LF. Traditional Morphometrics. In: Rohlf FJ, Bookstein FL, editors. Proceeding of the Michigan morphometric workshop. Ann Arbor, Michigan: The University of Michigan, Museum of Zoology; 1990. p. 77-122.

Mariguela TC, Benine RC, Abe KT, Avelino GS, Oliveira C. Molecular phylogeny of Moenkhausia (Characidae) inferred from mitochondrial and nuclear DNA evidence. J Zoolog Syst Evo Res. 2013; 51(4):327-32.

Marinho MMF, Langeani F. A new species of Moenkhausia from the rio Amazonas and rio Orinoco basins (Characiformes: Characidae). Zootaxa. 2010; 2577:57-68.

Marinho MMF, Langeani F. Reconciling more than 150 years of taxonomic confusion: the true identity of Moenkhausia lepidura, with a key to the species of the M. lepidura group (Characiformes: Characidae). Zootaxa. 2016; 4107(3):338-52.

Menezes NA, Weitzman SH. Systematics of the Neotropical fish subfamily Glandulocaudinae (Teleostei: Characiformes: Characidae). Neotrop Ichthyol. 2009; 7(3):295-370.

Mirande JM. Phylogeny of the family Characidae (Teleostei: Characiformes): from characters to taxonomy. Neotrop Ichthyol. 2010; 8(3):385-568.

Mirande JM. Morphology, molecules and the phylogeny of the Characidae (Teleostei, Characiformes). Cladistics. 2018: doi. org/10.1111/cla.12345.

Mirande JM, Aguilera G. Los peces de las selvas pedemontanas del nostoeste argentino. In: Brown AD, Blendinger PG, Lomáscolo T, García P, editors. Selva pedemonta de las Yungas. Tucumán: Ediciones del Subtrópico; 2009. p. 169-211.

Mirande JM, Koerber S. Checklist of the Freshwater Fishes of Argentina (CLOFFAR). Ichthyol Contrib Pec Crioll. 2015; 36:1-68.

Norris SM, Douglas ME. Geographic variation, taxonomic status, and biogeography of two widely distributed African freshwater fishes: Ctenopoma petherici and C. kingsleyae (Teleostei: Anabantidae). Copeia. 1992; 1992(3):709-24.

Oliveira GD, Marinho MMF. A new species of Moenkhausia Eigenmann, 1903 (Characiformes, Characidae) from the rio Amazonas basin, Brazil. Zootaxa. 2016; 4093(4):566-74.

Ornelas-García CP, Bastir M, Doadrio I. Morphometric variation between two morphotypes within the Astyanax Baird and Girard, 1854 (Actinopterygii: Characidae) genus, from a Mexican tropical lake. J Morph. 2014; 275(7):721-31.

Pastana MNL, Dagosta FCP, Esguícero ALH. A new sexually dichromatic miniature Hyphessobrycon (Teleostei: Characiformes: Characidae) from the Rio Formiga, upper Rio Juruena basin, Mato Grosso, Brazil, with a review of sexual dichromatism in Characiformes. J Fish Biol. 2017; 91(5):1301-18. DOI 10.1111/jfb.13449.

Persia DH, Neiff JJ. The Uruguay River system. In: Davies $\mathrm{BR}$, Walker KF, editors. The ecology of river systems. The Netherlands: Springer Netherlands; 1986 p. 599-629.

Quirós R, Bechara JA, Resende EK. Fish diversity and ecology, habitats and fisheries for the un-dammed riverine axis ParaguayParana-Rio de la Plata (Southern South America). Aquat Ecosyst Health Manag [serial on the Internet]. 2007; 10(2):187-200. Available from: http://dx.doi.org/10.1080/14634980701354761

Queiroz LJ, Torrente-Vilara G, Vieira FG, Ohara WM, Zuanon J, Doria CRC. Fishes of Cuniã Lake, Madeira River Basin, Brazil. Check List. 2013; 9(3):540-48.

Quinn GP, Keough MJ. Experimental desing and data analysis for biologist. Cambrigde: Cambrigde University Press; 2002.

Reia L. Revisão taxonômica das espécies do grupo Moenkhausia oligolepis (Teleostei: Ostariophysi: Characiformes). [Master Thesis]. Botucatu: Universidade Estadual Paulista "Júlio de Mesquita Filho"; 2018 [cited 4 Feb 2019]. Available from: Repositorio Institutional UNESP. Https://repositorio.unesp.br/ handle/11449/153684?locale-attribute=es

Reis RE, Albert JS, Di Dario F, Mincarone MM, Petry P, Rocha LA. Fish biodiversity and conservation in South America. J Fish Biol. 2016; 89(1):12-47.

Reyment RA. Reification of classical multivariate statistical analysis in morphometry. In: Rohlf FJ, Bookstein FL, editors. Proceeding or the Michigan morphometric workshop. Ann Arbor, Michigan: The University of Michigan; 1990. p. 123-44.

Ringuelet RA, Aramburu RH, Alonso de Aramburu AS. Los peces argentinos de agua dulce. La Plata: Comisión de Investicación Científica, Provincia de Buenos Aires; 1967.

Rohlf FJ, Bookstein FL. A comment on shearing as a method for "size correction". Syst Biol. 1987; 36(4):356-67.

Román-Valencia C, Vanegas-Ríos JA, García G, Maria D. Análisis comparado de las especies del género Bryconamericus (Teleostei: Characidae) en la cuenca de los ríos Cauca-Magdalena y Ranchería, Colombia. Rev Mex Biodiv. 2009; 80(2):465-82.

Sabaj MH. Standard symbolic codes for institutional resource collections in herpetology and ichthyology: an Online Reference. Version 6.5 (16 August 2016). 2016. Available at http://www.asih.org/, American Society of Ichthyologists and Herpetologists, Washington, DC.

Sidlauskas B, Chernoff B, Machado-Allison A. Geographic and environmental variation in Bryconops sp.cf. melanurus (Ostariophysi: Characidae) from the Brazilian Pantanal. Ichthyol Res. 2006; 53(1):24-33.

Soares IM, Azevedo-Santos VM, Benine RC. Redescription of Moenkhausia megalops (Eigenmann, 1907), a widespread tetra from the Amazon basin (Characiformes, Characidae). Zoosyst Evol. 2017; 93(2):255-64.

Svanbäck R, Eklöv P. Genetic variation and phenotypic plasticity: causes of morphological and dietary variation in Eurasian perch. Evol Ecol Research. 2006; 8(1): 37-49.

Taylor WR, Dyke GCV. Revised procedures for staining and clearing small fishes and other vertebrates for bone and cartilage study. Cybium. 1985; 9:107-19. 
Teresa FB, Romero RM. Influence of the riparian zone phytophysiognomies on the longitudinal distribution of fishes: evidence from a Brazilian savanna stream. Neotrop Ichthyol. 2010; 8(1):163-70.

Teresa FB, Romero RM, Langeani F. Pisces, Aquidauana and Miranda drainages, upper Paraguay River basin, Mato Grosso do Sul, Brazil. Check List. 2010; 6(4):596-601.

Teresa FB, Romero RM, Sabino J. Fish as indicators of disturbance in streams used for snorkeling activities in a tourist Region. Environ Manage. 2011; 47(5):960-68.

Tortonese E. Ricerche ed osservazioni sui Caracidi delle sottofamiglie Tetragonopterinae, Glandulocaudinae e Stethaprioninae (Teleostei, Plectospondyli). Bull Musei Zool Anat Comp Torino. 1942; 49(117):11-86.

Vanegas-Ríos JA. Taxonomic review of the Neotropical genus Gephyrocharax Eigenmann, 1912 (Characiformes, Characidae, Stevardiinae). Zootaxa. 2016; 4100(1):1-92.

Vari RP, Harold AS. Phylogenetic study of the Neotropical fish genera Creagrutus Günther and Piabina Reinhardt (Teleostei: Ostariophysi: Characiformes), with a revision of the CisAndean species. Washington (DC): Smithsonian Institution Press; 2001. (Smithsonian Contribution to Zoology; No. 613).
Webster MM, Atton N, Hart PJB, Ward AJW. Habitat-specific morphological variation among threespine sticklebacks (Gasterosteus aculeatus) within a drainage basin. PloS ONE [serial on the Internet]. 2011; 6(6):e21060. Available from: http://dx.doi.org/10.1371/ journal.pone.0021060

Yamahira K, Lankford TE, Conover DO. Intra- and interspecific latitudinal variation in vertebral number of Menidia spp. (Teleostei: Atherinopsidae). Copeia. 2006; 2006(3):431-36.

Zamudio KR, Bell RC, Mason NA. Phenotypes in phylogeography: Species' traits, environmental variation, and vertebrate diversification. Proc Natl Acad Sci U S A. 2016; 113(29):8041-48.

\section{(c) (i)}

Submitted October 09, 2017

Accepted January 14, 2019 by Fernando Carvalho 